\title{
Combining Work and Pension in Norway: Gathering Information and Imagining the Future'
}

\section{Anne Skevik Grødem}

Senior Researcher, Institute for Social Research, Norway

I Ragni Hege Kitterød ${ }^{2}$

Senior Researcher, Institute for Social Research, Norway

\begin{abstract}
The Norwegian pension system has provided unprecedented flexibility to combine work and pension drawing from the age of 62, and this has become a popular option. Using qualitative interviews with 28 older workers, we explore their information strategies and motivations. We find that many informants struggle to understand the various options and their consequences and use different strategies to shield themselves from insecurity: they downplay the issue or point to factors beyond their control. Two key motives for early pension take-up are the desire to secure the money for one's family in the event of early death and to get the money while still vigorous. Informants typically imagine life after 80 as quiet and with fewer material demands. In conclusion, the analysis shows how adaptations to the flexible pension system are embedded in notions of ageing, institutional trust, and a newfound sense of ownership regarding one's retirement savings.
\end{abstract}

\section{KEYWORDS}

Early pension drawing / flexible pension / information / older workers / pension planning / rational decision-making

\section{Introduction}

$\mathrm{n}$ response to an ageing population, a number of countries in Europe have redesigned their old age pension systems in order to encourage people to work longer and delay retirement (Ebbinghaus 2011; Jensen 2020; OECD 2019). Early exit routes have become less accessible and attractive, while the state pension age has been raised (European Commission and the Social Protection Committee 2018; OECD 2019). Individuals are made more responsible for securing a sufficient level of income in old age and are expected to be knowledgeable and active in planning for retirement (Breit \& Salomon 2015; Vickerstaff \& Cox 2005). There is widespread concern, however, that individuals have insufficient knowledge about how the pension systems in their countries actually work and thus, will not be able to make good decisions (Almenberg \& Säve-Söderbergh 2011; Chan \& Stevens 2008). How individuals approach these choices and the information strategies they use, are therefore points of concern in most countries around the world (Boisclair et al. 2017; Moffatt \& Heaven 2017; van Rooij et al. 2012). This

\footnotetext{
${ }^{1}$ You can find this text and its DOI at https://tidsskrift.dk/njwls/index.

${ }^{2}$ Corresponding author: Ragni Hege Kitterød, hege.kitterord@samfunnsforskning.no, Institute for Social Research, Norway.
} 
article contributes to this debate by analyzing how individuals seek information about their retirement options and what concerns guide their decisions. The analysis is based on 28 qualitative interviews with older workers in Norway, a country where the pension system offers considerable flexibility with regard to combining work and pension and when and how to start pension take-up.

In Norway, 'when to start drawing pension' and 'when to stop working' are almost entirely decoupled. Most workers can start to draw pension at age 62, and they can continue in employment-and build their pension savings further-up to, in principle, age 75 . During this period, they will have very high disposable incomes. The downside is that early take-up translates into lower annual sums for the rest of one's life. This is the principle of actuarial neutrality, which stipulates that the total amount of pension over the life course should be the same regardless of when the individual starts takeup. Workers in Norway accrue notional retirement 'savings accounts' and distribute the money in this account over the course of their lives as retirees. Few other countries offer similar flexibility with regard to both take-up and abilities to combine wages and pension in their mandatory state pension. Norway thus provides an apt setting for investigating how older workers reason about the financial aspects of their retirement decisions, including their thoughts on distribution of the finances over their life course.

Combining work and pension is a popular option among older workers in Norway: in $2019,50 \%$ of men and $25 \%$ of women aged $62-66$ drew pension from the National Insurance while still working. We start from the assumption that their motivations for doing this are rooted in concerns that go well beyond mere financial calculations, including consideration of information strategies, perceptions of various forms of savings, and preferences for spending here and now versus later as well as considerations of health and life expectancy. These issues are sociological rather than financial. We formulate two research questions: First, to what extent do workers in their late 50s and 60s seek information about the pension system and their own pension rights before making their decisions and what are their information strategies and sources? Second, which concerns and priorities motivate early take-up at the expense of lower incomes later? In exploring the second research question, we dig into the reasons that people provide for starting to draw (or not draw) pensions benefits, how they spend or plan to spend their pension drawings, how they reflect on possible tradeoffs between time and money, and their thoughts and possible concerns about their income in retirement.

Since most countries do not offer their older workers the option of drawing pension early at the expense of lower incomes late in life, previous literature on decision-making in this context is scarce. This is also true in the Nordic countries, despite the similarities between the Norwegian and the Swedish pension system (Salomon \& Solem 2020). The study of pension take-up prior to labor market withdrawal sits uneasily at the intersection between the literature on financial planning on one hand and the literature on extended working lives on the other. The former overlooks the particular vulnerabilities facing older workers, including most insights from social gerontology, and focuses mainly on decisions made earlier in life. This is even true for the literature on pension savings (see for instance Almenberg \& Säve-Söderbergh 2011; James et al. 2020; Prabhakar 2017). The literature on extended working lives and retirement behavior typically analyzes the decision to withdraw (or not) from employment (recent contributions include Grødem \& Kitterød 2021; Hellevik \& Herlofson 2020; Jensen 2020; Nivalainen et al. 2020) and downplays pension take-up as a financial decision.

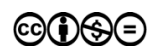


In what follows, we first elaborate on the intersection between behavioral economics and the sociology of late careers and old age, emphasizing, in particular, the barriers to (economically) rational decision-making and the imagined life course. We then describe the Norwegian context in more detail before presenting our data and findings. The article ends with a concluding discussion.

\section{Economic rationality and the older worker}

The Norwegian pension system was reformed in 2011, and the post-reform system allows for far more flexibility and hence, more individual choice than the old one. The pension reform was explicitly aimed at creating a system that is more transparent, allowing individuals to make well-founded choices (Breit \& Salomon 2015). The new pension system is thus based on the assumption that people will be able to gather and use available information and undertake cost-benefit analyses in their preparations for retirement and in deciding how to accommodate the flexible options. Similar assumptions dominate in several western countries (see for instance Almenberg \& Säve-Söderbergh 2011; Brown \& Vickerstaff 2011; Moffatt \& Heaven 2017). A number of contributions, however, show that this is not how most people approach retirement decisions (Barr 2014; Bergene \& Drange 2015; Chan \& Stevens 2008; Hermansen \& Midtsundstad 2013). Most people do not invest much time and energy in investigating their options, and they tend not to make financially optimal decisions. Building on insights from the literature on bounded rationality and behavioral economics, Barr (2014:61) distinguishes between 'imperfect information' and 'non-rational behavior' as two distinct weaknesses of national pension markets.

The problem of imperfect information occurs for two fundamentally different reasons: individuals may not bother to access available information, or the information they need does not exist. While 'not bothering' may sound irresponsible, it can be argued that ignorance can be rational. Downs (1957) argued that it is rational to remain ignorant when the cost of acquiring information is greater than the benefits one can derive from the information. Pension is typically perceived as a technical, abstract, and fundamentally dull issue (Bergene \& Drange 2015), and many older workers may prefer to spend their time doing something more rewarding than digging into the intricacies of the pension system. Individuals who are far from the normative retirement age typically show limited interest in pensions, and even workers approaching this age can seem disinterested if they lack clear milestones to indicate when they should retire (Ekerdt et al. 2001).

Moreover, understanding pensions requires a certain level of financial literacy that many people simply do not have. The OECD regularly measures financial literacy across different countries, and the results are typically disheartening. In the scaling system used, a score of 21 indicates that an individual has acquired a basic level of understanding of financial concepts and applies some prudent principles in their financial dealings, and average scores for countries rarely exceed 14. Norway is one of the countries that score relatively high (an average of 14.5 in 2016, OECD 2017) yet still well below the threshold of 21. It is more than likely that low financial literacy is a barrier towards gathering and understanding information about national pension systems (see for instance Almenberg \& Säve-Söderbergh 2011; Boisclair et al. 2017). 
Individuals who are eager to and able to access the available information may still be unable to grasp the full picture. In systems based on actuarial neutrality, decisions about retirement and pension take-up would ideally require information about one's own death date, which, thankfully, is almost always out of reach. In addition, many pension schemes are in fact very complex, and sometimes experts disagree on what options and adjustments are actually most beneficial in economic terms (Lien 2012). The 'financially optimal' decision may be impossible to determine. In addition, employees face uncertainty with regard to later working life and the transition to retirement. As noted by Ekerdt et al. (2001:169), 'there appear to be eddies in the stream of workers flowing self-consciously toward retirement-people who do not readily know or admit their direction'. Similarly, Moffatt and Heaven (2017) hold that models of retirement decision-making, which view people as highly rational, should incorporate qualitative findings highlighting people's lived experiences and trade-offs that they make in the process of undertaking retirement-related decisions. Acquiring optimal information and planning in accordance with these insights is of little use if circumstances keep shifting, and the ultimate outcome is, to some extent, beyond individual control.

The notion of 'non-rational behavior' (Barr 2014) refers to informed decisionmaking that is suboptimal in financial terms. One mechanism that is likely to be important for our purposes here is 'present bias', that is, the preference for rewards today rather than tomorrow (Barr 2014; James et al. 2020). This mechanism is well known in behavioral economics, but we know less about how the implication of 'present bias' may change over the life course and how it interacts with feelings of uncertainty and attitudes toward ageing. The choice that older workers have to make in Norway-between higher disposable incomes in their 60s and lower pensions later or higher pensions after retirement-is an unusual one. The literature on pension savings brings up the issues of imagined life courses (James et al. 2020), present bias, and inertia (Barr 2014; Foster 2012), but these studies tend to focus on the accumulation phase. The international research literature provides few pointers with regard to how individuals reason around spending their accumulated savings (but see Newall \& Peacey 2021).

Within social gerontology, an important approach to understanding the relationship between ageing and money theorizes consumption practices later in life as embedded in cultures of ageing and generations (Price \& Livesey 2015). This notion draws on Gilleard and Higgs' (2000) concept of 'the third' and 'the fourth' age; the third age is linked to the notion of 'successful ageing' and images of individual fulfillment and consumption. The fourth age, by contrast, is a 'social imaginary' characterized by frailty, withdrawal, and the loss of agency. Qualitative interviews suggest that informants happily plan for and save for the third age and death, but they neglect the period between 'active aging' and death, that is, the fourth age (Price et al. 2014). In the fourth age, they reason, they will be in a care home, and 'the discussions about care have no detail, no timelines, no trajectories and no plans' (Price et al. 2014:406). The third age is for consumption and that is when savings will be spent and capital, released. The fourth age is death's waiting room, and money available in this phase has little value.

In summary, the literature indicates that many informants will limit information gathering because they find pensions overly complex or because they feel that there is too much insecurity to make an optimal decision. We also expect to find a certain degree of present bias in the sense that those who have started—or intend to start-early takeup do so because they value rewards now over security later. We do not know, however, 
how present bias plays out when individuals plan for the final years of their lives. Our predictions are mainly based on findings in studies of savings behavior and opt-out options in occupational pensions. We do not know how this will play out in a system in which individuals' entire retirement savings are subjected to the principle of actuarial neutrality and in which labor market behavior in ones 60s and the size of the pension in ones 80 s are directly linked. We therefore proceed in an explorative fashion.

\section{The Norwegian context: senior employment and pension regulations}

Norway, as noted, provides a particularly useful context for studying how older workers make decisions and how they think about the value of money now versus later. The architecture of the post-2011 pension system allows for early take-up and for flexible combinations of wages and pensions but at the cost of significantly lower pensions in later years. In this section, we present the pension system in more detail and provide further information about Norway as a context for our findings.

The Norwegian pension system consists of three parts. The state National Insurance scheme covers all residents. The public sector contractual pension (AFP) scheme covers all public sector employees, while the private sector AFP scheme covers about $50 \%$ of private sector workers (Hippe et al. 2018). The two AFP schemes are similar for all covered; thus, there is no variation within each sector, but there are important differences between the public and private scheme. All employers are mandated to offer occupational pensions. Again, there are important differences between the public and private sector, and there is also a wide variety within the private sector (Grødem \& Hippe 2020).

Since 2011, the National Insurance old age pension in Norway has been fully flexible, allowing take-up between ages 62 and 75 on actuarially neutral terms. Actuarial neutrality implies that the total amount of pension over the life course should be the same regardless of whether one starts take-up early or late. Therefore, the earlier the take-up, the lower the annual sum. This principle also means that individuals can combine wages and pension and that annual pension amounts are not reduced for earnings. Reducing pensions for earnings makes no sense when the individual 'pays' for early take-up through lower annual rates for the rest of their life. Older workers may take a partial pension in steps of $20 \%, 40 \%, 50 \%, 60 \%, 80 \%$, and $100 \%$ of the full annual pension. The proportion can be changed annually, and pension drawings can be stopped at short notice. The 2011 reform also established the principle of life expectancy adjustment, meaning that annual pension amounts are reduced in accordance with the relevant birth cohorts' life expectancy (though individual pensions are always life-long). As life expectancy continually increases, pensions will be lower in the future, and future workers will need to extend their working period in order to compensate (Grødem \& Hippe 2020). Flexible retirement on actuarially neutral terms can thus be seen as a functional equivalent to raising the pension age (for more on the Norwegian pension reform, see Pedersen 2017). The new rules are in full effect for cohorts born in 1963 and later, while transitional regulations apply for cohorts born between 1954 and 1962 .

The AFP scheme was originally an early retirement scheme that allowed for early retirement at age 62 on comparatively generous terms. It was renegotiated as part of 
the pension reform process. In these negotiations, the public and private sector parted ways (Hagelund \& Grødem 2019). The trade unions in the private sector accepted that the principle of full flexibility on actuarially neutral terms was implemented in AFP in 2011, while the reform process in the public sector took much longer. As late as 2019, when our interviews took place, the principle of actuarial neutrality was only partially implemented in the public sector. For that reason, we interviewed only workers who were employed in the private sector at the time of the interview, and we do not present public sector AFP and occupational pension further.

Private sector AFP, like the National Insurance pension, can be claimed from age 62 on actuarially neutral terms, implying that early take-up translates into lower annual rates. As such, it is a top-up pension for those who qualify. In order to qualify, the employee must be with an employer that is covered when they turn 62 and must have worked in a covered firm for at least seven out of the preceding nine years. Hence, an AFP benefit can easily be lost even if one has contributed to the scheme throughout one's working career. This can happen for reasons beyond individual control, such as health problems or plant downsizing (Hippe et al. 2017). For this reason, AFP may contribute to the sense of insecurity and lack of predictability that some older workers feel (Moffat \& Heaven 2017).

Private sector occupational pensions are mandatory (since 2006), but there is a great variety in savings rates. Generosity varies from a required minimum of $2 \%$ up to voluntary employer yearly savings rates of $7 \%$, and a top-up can be made for higher incomes (Grødem \& Hippe 2020). Practically all the new occupational pension schemes in the private sector are pure defined benefit (DC) savings schemes. Importantly, they offer payment for a period of 10 years or at least until the claimant turns 77 . Most private sector workers will therefore see a drop in their incomes after age 77, regardless of when they start drawing National Insurance pension and AFP.

A further important difference between the firm-based occupational pensions on one hand and National Insurance pension and AFP on the other, concerns the rules for inheritance. If a person dies before he or she has used up the money saved in DC schemes, their beneficiaries inherit the money according to rules specified for the different schemes. The notional savings made in AFP and National Insurance return to the pension schemes and cannot be inherited. The family members lose this money when the insured person dies.

To enhance the populations' ability to make good decisions about retirement, the Norwegian Labor and Welfare Administration has developed a pension calculator where individuals can $\log$ in to check their notional pension savings and projected annual amounts (Breit \& Salomon 2015). Private actors, including the major insurance companies, have developed similar calculators. The new flexibility also increased the demand for financial advice, which created a new market for the finance industry. One study showed that media coverage of the new system often took the form of expert advice and that advisors in the finance industry heavily dominated the expert sources (Hagelund \& Grødem 2017). The finance industry also offers a number of courses and seminars targeted at employers or older employees. This industry thus plays an important role in 'translating' the pension system for the public.

The older workers approaching retirement in 2019 belong to the first generation in which both women and men have had fairly stable careers during their prime working age, although women still perform more part-time work than men and have more 
extensive parental leaves (Ellingsæter \& Jensen 2019). Compared to many other European countries, in Norway, employment rates among older adults are high, reflecting a tight labor market and people's preferences and opportunities to work well into their 60 s, as well as the beneficial incentives structure in the pension system. In $2018,72 \%$ of Norwegians aged 55-64 were employed, which is considerably above the EU-28 average (Eurostat 2019), and in recent years, the average actual retirement age has increased in Norway (Bjørnstad 2019).

Norwegian adults in their 50s and 60s typically entered the housing market in the 1990s and 2000s and have benefitted from a large increase in the values of their homes and other real estate. This is particularly true for those living in the Oslo region. In addition, a large proportion of adults in Norway own a cottage or a secondary home. Thus, many people now approaching retirement may count on a kind of private financial safety net later in their lives. Poverty rates among elderly pensioners have fallen sharply since the turn of the millennium. The most recent data indicate that $8.5 \%$ of old age pensioners had persistently low incomes, which is a lower figure than that of the general population (Epland \& Thorsen 2019:53).

\section{Data collection}

Our analysis is based on qualitative interviews with 28 senior workers in Norway, conducted in late autumn 2019. We wanted to capture a wide range of perspectives, thoughts, and considerations regarding flexible retirement options and selected informants based on the following criteria: an age between 55 and 66 years, in active employment in the private sector, and, for informants 62 years and older, the use of a combination of pension drawings and paid employment. Moreover, we required that informants had at least one child, lived with a partner or had previously done so, and had different levels of education. The decision to limit the sample to private sector workers was made to ensure that all informants related to similar occupational pensions, as described above. As for informants 62 years and older, the decision to include only those claiming pension benefits was made because we were particularly interested in how they used the extra funds they had access to. Also, we assumed that those who claimed pension benefits had made more deliberate considerations as to whether to start uptake or not, compared to those who did not claim pensions, as suggested by Dahl and Galaasen (2013). We did not include fully retired individuals in the same age group, as we assumed that the decision to retire would be determined by a number of factors beyond the financial and because we wanted to interview those who could view pensions as 'extra liquidity' rather than as their main source of income.

The informants were recruited by a survey institute, Kantar, via Facebook ads. Interested users could check whether they were in the target group, and those who passed were contacted by telephone so that the screening information could be verified. Prior to the qualitative interview, participants were given a letter outlining the purpose of the study and their rights to opt out at any time. All informants signed a consent form and were rewarded with a NOK 500 (app. 50 Euro) gift card. This amount was sufficient to cover travel costs and any other expenses associated with the interview and to thank participants for their time. We have no reason to believe that this affected the recruitment process. 
Interviews took place in Kantar offices. The interviewer first collected standardized information about gender, age, marital status, employment (full-time or part-time), and the number of children. The rest of the interview was semi-structured and based on a comprehensive interview guide made by the research team. The interviewer was employed by Kantar and acted as our research assistant. We had several discussions with him to make sure he fully understood the purpose of the study. We also watched a sample of interviews via live streaming and gave feedback to the interviewer after each session. The interviews were transcribed by Kantar's transcribers and transferred to us anonymously. We believe that outsourcing the interviewing to a third party had both costs and benefits. In this case, we had two main reasons for doing this. First, we assumed that outsourcing recruitment to a professional firm would ensure a more varied sample than the samples we might have obtained using other methods. Second, and more importantly, the main topics of the study dealt with the informants' knowledge and utilizations of the flexible options in the pension system. Based on previous studies, we had reason to believe that informants' knowledge could be limited, and we feared that informants might feel embarrassed to display their ignorance to a researcher in the field. The interviewer sometimes feigned ignorance if informants asked for more detail but also provided pieces of information throughout the interview. This turned out to work very well. Although we may have lost some information as a result of not being able to see informants' body language and the lack of the ability to follow up with more in-depth questions when informants brought up an unexpected topic, we believe that the information lost in this way is not crucial.

In light of later developments, it is worth pointing out that our informants were interviewed before the COVID-19 pandemic hit Europe. Considerations and insecurities linked to the pandemic and the ensuing social distancing measures are thus not reflected.

For practical reasons, all informants lived in the Oslo region. We interviewed 15 men and 13 women; 10 were aged 55-61 years and 18, aged 62-66 years. Twenty-three of the informants were married, two were cohabiting, and three lived alone; all were native (nonimmigrant) Norwegians. Seven held a master's degree, 13 held a bachelor's degree, eight had a secondary or primary level of education, and there was a wide variety of professions represented. Five informants (those aged 55-56 years) will accumulate National Insurance retirement pension according to the new accumulation rules that took effect from 2011, while informants 57 years and older will accumulate pension according to both new and old rules. However, the flexible options for combining work and pension benefits introduced in 2011 apply to all cohorts. An overview of the informants is provided in the appendix. The numbers assigned to the informants in the appendix table reflect the order of interviewing and are used to identify informants in the quotes in the analytical section.

To analyze the data, we first read the interview transcripts one by one, examining the thoughts and reflections of each individual informant. We strived to understand their perspectives and considerations while at the same time searching for common patterns in practices, reasoning, and the way the informants talked about their pension planning or lack thereof. We used codes based on the topics in the interview guide and supplemented them with codes that emerged from our reading and interpretation of the interviews. Working with this study, we alternated between using the codes and rereading the entire interviews in order to ensure that we understood the various statements correctly within the context of each individual situation. In particular, we looked

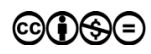


carefully at the informants' various reasons and reflections concerning why they had decided to draw pension benefits, how they would spend the money, and their thoughts about their household finances in retirement. For several of the participants, these topics were closely intertwined, and some provided slightly diverging information and opinions throughout the interview. As we will see, some also expressed themselves somewhat imprecisely and hesitantly and used many auxiliary words, and this probably suggests that they found some topics difficult or had not thought much about them.

\section{Analysis}

\section{The role of information and advice}

As we would expect from studies of financial literacy and information-gathering under the new pension system, there was considerable variety among our informants in how much they knew about pension regulations, their own pension schemes, and to what extent they actively sought advice and information and prepared financially for retirement. On one hand, there were informants who appeared to be quite knowledgeable about both the system at large and their own pension package. These informants were either 62 years or older, and/or had a background in economic studies, economic management, or the finance sector. These best-informed informants appeared proactive and collected information from several sources, such as public and private web portals, counselors in banking and insurance companies, HR managers, and the popular media. The best informed had typically started to plan whether and how to draw pension benefits from the age of 62, several years in advance, and talked in terms of cost-benefit analyses, a calculated risk, and keeping track of their Excel schemes. These informants had arrived at different conclusions depending on their particular situations and preferences, but they had thought carefully through the pros and cons of various solutions.

On the other hand, some informants appeared to be fundamentally alienated. Some of them were not even aware of the flexible pension option, while others had learned about it more or less by coincidence. These informants typically did not have education at the college/university level, and they were employed in working class jobs (e.g., transport, reception, kindergarten). This is however not the full picture. There were also informants in this group with higher education and/or managerial jobs; this particular group tended to be younger than well-informed informants with higher education and typically reasoned that retirement was still some years away and many factors could still change. These less-informed respondents sometimes thought that pension-related issues were completely incomprehensible, a 'rough terrain', and extremely boring, as demonstrated by the following quote: '...then we return to the whole pension thing that is so unclear and incomprehensible, and I think it is so strange for me [....] No, I think that's weird, the whole system really' (\#19, woman, 63, reception).

The less-informed respondents were (unsurprisingly) less systematic in their quest for information and typically relied strongly on a few informal sources: their HR managers, a counselor from a financial institution hired by the employer, or family or friends. For instance, one informant explained that he knew very little about his own pension rights but had started to draw pension at the age of 62 because his partner had told him to do so. She was the 'minister of finance' in their relationship, and he relied fully on her 
advice (\#17, Man, 64, transport). Likewise, another informant was completely unaware of her options until her HR manager told her about the possibility to start claiming AFP benefits shortly before she turned 62 and portrayed this as a very generous option. The informant commented that she had never bothered to think through these questions herself and 'blindly' trusted the HR manager's recommendations (\#14, woman, 64, creative enterprise).

Some of the insecurity stemmed from the complexity of individuals' lives and working careers. Some of our informants had tried to seek information but were overwhelmed by the complexities that arose in their particular case. This included individuals who had worked in different countries, alternated between the public and private sector, or had spells of self-employment. Some of our informants confirmed the concern brought up by Breit and Salomon (2015) and noted that they had been more confused after trying the online calculators. In other cases, the complexity stemmed from the fact that it is impossible to divine the future. The best-informed informants were aware of the importance of life expectancy; one called it 'a bet against the state' or 'a genes lottery'. In addition, there were a number of events beyond individual control, such as an employer changing their occupational pension scheme, or the potential of reorganizations to lead informants to lose their AFP. Some of the younger informants also worried that 'those politicians' might change the rules in the years to come.

While we found some tendencies linked to age and education, it was difficult to sort the informants into two neat piles: the 'well-informed' and the 'confused'. There was a great deal of uncertainty across the board, and practically none of the informants were confident that they had made, or were about to make, the optimal choice. Practically all the informants had engaged in some information-seeking strategies: pondering the advice of family members, colleagues, or friends who they regarded as more knowledgeable, taking a course organized by the employer, trying out the online calculators, and reading about pension coverage in the popular media. Practically all knew the basics of the reformed pension system; in particular, the principle of working longer and getting a higher pension later was well established. Although informants knew that this was the main principle, some of them worried about possible loopholes and exceptions, and many had only a vague idea of what this actually implied for them. Strikingly, many of the informants who had started take-up seemed to metaphorically cover their ears and refused to listen to information that might make them doubt their choices, as illustrated by the following quotes:

I kind of thought I should sit down one day and do the calculations, but it is too late now. I have been drawing (benefits) for almost five years now (\#25, man, 66, economist).

Anyway, I was told that I ought to [start take-up], but others have been told not to do so. And I'm thinking like, yes, maybe I made a mistake there, or well...But again, you don't know. What is done is done (\#19, woman, 63, reception).

But I thought that now I have to stand by what I have done. So now, I just have to let it play out..... In [the tabloids] on Saturdays, there is always something about pensions [....]. And then you have slightly different statements. Some say [early take-up] paid off, while others say it did not pay off. Then, I think, don't read this because you have made a choice now. I can't turn back time (\#22, woman, 64, sales). 
These three informants had started take-up but remained unsure whether this was the 'right' choice. Even knowledgeable informants had to stop the information-gathering somewhere and 'stand by what they had done'. At some point, informants just wanted to avoid the good advice, the doubts, and insecurities.

\section{Why start early take-up?}

We imagined that informants could approach the issue of whether to start take-up in one out of two ways: they could start (or plan to start) take-up early because they believe this would give them the maximum total amount or because they want extra money to spend, invest, or give to children. The reality, we found, was far more complex. As already shown, most informants were confused with regard to what would 'pay off', and many took advice from more or less random 'experts'. Some started early take-up because they wanted to secure the rights they had before the employers snatched them away (one informant said he had been told by a professional advisor, 'When you get the chance, take the money and run'). Besides, informants typically mentioned more than one reason for drawing pension throughout the interview. In the same breath, they could talk about how they thought it was 'smart' to secure the money and also about how they enjoyed having extra funds for various purposes.

Motivations for starting early take-up, then, were not clear-cut, neither were saving strategies or money management once they had the money in hand. Here, too, we found a continuum: some informants were determined not to touch their pension savings until they were fully retired, while others did not exactly know where the money went-it just disappeared into the regular household budget. In between these extremes were informants who saved some and spent some and those who saved but allowed themselves to dip into savings if they needed extra cash. Savings strategies also varied: some paid off loans, others co-invested in property with their children (in other words, helped their children in the housing market), many saved in a bank account or in stocks or mutual funds, and one informant saved the money in cash at home because the bank currently pays no interest anyway.

Hence, we did not find clear distinctions between smart investors and hedonistic spenders. However, two motivations for starting early take-up materialized: securing the money for family and living an active life while they still could.

As noted, DC schemes in the private sector can be inherited by the deceased's family, while DB schemes, hybrid schemes, and AFP and National Insurance pension are lost when the insured person dies. The awareness of this among our informants was strongsurprisingly strong, given how confused many of them were about the system at large. Informants typically described their pension accrual as something they were entitled to and that should not go to 'the larger society' or 'the general pension scheme' if they themselves passed away. Some talked about securing the money for themselves and enjoying it while they could, while others wanted their families to have the money ('If something should happen, at least my husband or my children will get the money'). Some portrayed such reflections as a main motivation for pension take-up, while others mentioned them more as secondary thoughts - they were not sure if it was a wise decision to draw pension benefits but had started more or less by chance and commented that their money would at least not 'go back to the system', as a reasonable hindsight justification. 
The informants who said they drew or would draw pension early in order to secure the money for their families, referred to this as a purely financial decision. They would take the money, store it, and continue to work and live as before. Others, however, wanted the money because they wanted to make some changes to their lives: either downscale work, travel more, or both. These informants clearly made a distinction between the value of money now versus the value of money later: Now, they were relatively young, fit, and vigorous. Later, they would be old and have very different needs and priorities. For some, this was an argument for downscaling work and enjoying the good life:

No, then I think that [both my husband and I] like to be in good shape, and it would be nice to have more time while we can still go for long walks and stay outdoors and take long ski trips, hikes in the mountains, bike, and go out with the boat while we are still vigorous enough to enjoy it (\#2, woman, 56, project manager in bank).

Regardless of whether informants planned to retire early or not, they typically communicated clear distinctions between the value of money now versus the value of money later. They typically conveyed the belief that they would lead more quiet lives as they aged and thus, would not need that much money later in life. This image was surprisingly strong among our informants. The image they presented was not one of misery, dementia, and the need for care but rather of peace, rest, and moderation:

It is more important to have that money a little earlier too. So that you have a bit of [money] and are in good health in your late 60s and maybe get to spend that money rather than just having, like, new wheels on the walker. You don't need to change the tires on that one (\#23, man, 56, sales, strategic planning).

So it does not cost that much to [...pursue my hobby]. And I have books to last me until my late 80s: petrol for the lawnmower, milk for my tea. [...] I simply believe that the expenses do not need to be that big when you have passed 70 (\#16, man, 64, IT development).

Informants did not typically have clear ideas about when this 'later' started, but most indicated some time between ages 70 and 90 . Typically, however, these reflections came up when the interviewer reminded them that their occupational pension probably ended at 77 , and the informants responded by thinking out loud about what life would look like at this point. As the quotes exemplify, they imagined quieter lives with simpler needs: milk in the tea, books, and functioning walkers and lawnmowers.

A final point should be mentioned with regard to early take-up: some informants used or planned to use this as a substitute for health-related benefits. They enjoyed their work but thought it was too tiring to work full time. They did not want to take sick leave or to discuss possible adjustments with their boss but would rather solve the problem by working reduced hours combined with pension drawings. For instance, one participant explained that when his former employer had to downsize some years ago, he began to consider drawing pension benefits. An important driver was that he often got very tired because of health-related pains. Even though he was soon offered a fulltime job in another firm, he preferred to continue his adaptation with pension take-up 
and reduced working hours, which he believed made him feel better. Other informants considered similar adaptations in the near future.

\section{Living with uncertainty}

Our informants are consistently told, via the media and by authority figures, that they need to make 'smart' decisions with regard to pensions. Many felt a little guilty that they had not spent more resources on researching the issue, and practically nobody was confident that they had made the optimal decision or, for those younger than 62, would be able to do so. This created an uncomfortable tension, which our informants developed strategies to manage. The imagined life course, where informants tell themselves that their need for consumption will decline sometime in their 70s, can be seen as one such coping mechanism, a way to create predictability in an unpredictable landscape. Besides, we found that our informants placed a great deal of trust in the institutions. Our informants reasoned that if things seemed to work out pretty well for most people in retirement, it should go well for them too. Moreover, they typically expressed great confidence in the welfare state; there would always be some type of safety net. 'We live in Norway after all', one informant said, apparently inferring that 'Norway' was in itself a form of security. It is worth noting that the same informants could also express distrust in politicians (who might change the rules) and employers (who might alter their occupational schemes), and some of them had little detailed knowledge about the pension system as such. Taken together, this suggests that the institutional trust is general rather than specific. Older workers may not trust politicians, employers, or even individual welfare schemes, but they still trust that the Norwegian welfare system will somehow take care of them (see Ellingsæter \& Pedersen 2016 for similar findings on the family policy system).

In addition, many informants highlighted the other assets they had access to. Many of our informants had little or no debt, and when asked whether they had private pension saving schemes, several pointed out that they considered repaying their loans to be the best way to save for retirement. In addition, many had stocks and bonds, most owned homes in the Oslo region, and many also had a cabin, a pleasure boat, and/or a caravan. These assets, in addition to their homes, were typically fully paid for and could be sold in order to free up capital. Strikingly, many informants envisioned moving to smaller flats or out of the urban center. Many informants expressed a willingness to downscale and emphasized how they would be perfectly content with a frugal lifestyle. Across the socioeconomic spectrum, participants would talk about priorities, downscaling, and the option of realizing assets. In addition to cheaper or more modest housing, one could always manage with a smaller car, one car instead of two, less expensive holiday trips abroad, etc., and thus be able to realize the vision of an active 'third age'.

Interestingly, while most respondents expressed little worry for their personal finances in retirement, some commented that the younger generations would probably be worse off. They would have to plan more carefully and start saving at an early age, and they would need to discuss pension benefits with their employers. Because of increasing life expectancy, they would also need to work longer in order to obtain reasonable pension payments. Compared to the younger generations, the participants in our study believed that they themselves belonged to a generation that had 'drawn the 
golden ticket' and were indeed lucky not to have to worry much about their future pension payments.

\section{Discussion}

Older workers in Norway have been granted a great deal of flexibility and opportunities to tailor their pension to their needs. Pension can be taken early or late, fully or partly, and one can continue to work full-time or part-time while drawing pension. This gives individuals considerable freedom in a certain period of life, but it also exposes them to some potentially tough choices. Through qualitative interviews with older workers (aged 55-66 years), we have investigated two interrelated questions: to what extent do older workers seek information about the pension system before making their decisions, and which concerns and priorities motivate early take-up at the expense of lower incomes later?

As expected, based on the literature in the area (see for instance Barr 2014; Bergene \& Drange 2015; Breit \& Salomon 2015), we found that there are a number of barriers to information-seeking concerning this topic. Some informants read up, gathered information from several sources, and tried to make informed choices, but many pounced on whatever advice they were given by someone they assumed knew better: a colleague or manager, friend or family member, or an expert at a course their employer sent them to. Many of our informants found pensions boring or 'weird', and many undoubtedly had limited financial literacy. Other informants displayed excellent financial literacysome of them had backgrounds in economics or accounting-and had a good overview, but they also knew that there were limits to their knowledge. They knew that in order to make optimal decisions, they would need to divine their own date of death. They also knew that the system in itself is complex and contains a number of pitfalls (most severely, the risk of losing AFP rights for individuals below the age of 62), and some of them had found that even the professional experts were unable to give exact advice on 'what pays' (Lien 2012). In some ways, we could say that the main difference between the best-informed informants and the rest was that the former were more precise with regard to why it was impossible to 'be smart'.

So far, our findings are in line with expectations. The desire to be 'smart' combined with insufficient information created a tension for most informants, and existing literature says little about how older workers cope with the discomfort such tension entails. We found that one widespread coping mechanism was to downplay the issue, while often accentuating the inherent unpredictability of life. Another was to shield oneself from information once the decision was made. A third was to design a prospective life course, where they 'knew' that demands for consumption would be lower at some point. A fourth option was to emphasize their trust in the generic Norwegian welfare system, while also pointing to property and consumption goods they owned and could sell and their ability to live frugally on lower incomes.

Our second research question concerned the informants' valuation of money now versus money later, which speaks to what is termed 'present bias' in the literature. As noted, we know little about the specificities of such bias among workers approaching retirement and, ultimately, the final phases of life. Our observations regarding the imagined life course are highly relevant for this question. Imagining a quiet phase toward 
the end of life not only gives a sense of control, it also assigns a significantly higher value to money one receives in ones 60s over money received in one's 80 s. The way our informants talked about this went beyond the present bias known from the economic literature-our informants honestly believed that they would desire money less in 15-20 years than they did at present. In their 60s and well into their 70s, they envisioned an active life of traveling and consumption; in their 80s, they envisioned a more passive, yet content, life. These visions were informed by a strong sense of trust in Norwegian welfare institutions, which were assumed to be strong enough to cushion any overly negative outcomes.

Money received 'now' also had alternative functions beyond mere consumption. The two alternative functions we identified indicate certain unintended consequences of transforming a pension system from mainly DB with a fixed pension age, to a DC (savings) system with flexibility and actuarial neutrality. One seems to happen at the ideas level: Traditionally, old age pension has been understood as collective insurance against the 'risk' of being old. In the new institutional setup with full flexibility and notional pension accounts for individuals, some older workers have come to view their pension accrual as their money that they want to secure for themselves and their families before death cheats them out of it. This logic seems to underpin at least some of our informants' thinking and is a key factor when informants (plan to) start pension withdrawal early and save/invest the money. Informants who follow this logic want to secure the money for their families in the event of their own death because it is rightfully their money. In this, we may see the imprint of the finance industry as a key actor in making sense of the new pension system (Hagelund \& Grødem 2017).

The second (officially) unintended consequence relates to the use of flexible old age pension as a substitute for health-related benefits. Some of our informants said they wanted to downscale because their health situation no longer allowed for fulltime work. These informants avoided taking up health benefits—as might have been their right—and opted instead, for partial retirement. This spared them the hassle and potential indignity of having to apply for benefits with complex entrance criteria, but it also meant that they would receive lower pensions for the rest of their lives. Similar adaptations can be imagined for unemployment. This suggests an individualization of risk for workers above the age of 62 , which, at worst, will weaken their protection both as workers and as users of welfare services.

The coping strategies of older workers who have to make financial decisions in the midst of uncertainty, the influence of the imagined life course (the 'third and 'fourth' age) on financial decisions, and the creative ways in which these workers may use the flexibility that the system allows, are all topics that are largely unexplored in the existing literature. The literature on financial planning, including saving for retirement, tends to focus on earlier life phases, while the literature on older workers' decision-making and thoughts on retirement focuses heavily on the decision to withdraw from employment. Against this background, we believe the analysis presented here adds to the literature. Nevertheless, this study has limitations regarding the degree of generalizability. First, we have stressed that the Norwegian pension system offers flexibility and an incentive structure that is different from those of most other countries. This makes it an apt case for investigation of older workers' financial decisions as we have argued, but it implies that findings must be translated to other contexts rather than 'generalized'. Moreover, Norway is a rich country with a generally affluent population. It is likely 
that older workers in less affluent countries with less comprehensive welfare institutions will express more financial stress and less institutional trust. It is even possible that the image from Norway would be different if the interviews had been carried out a few months later, when the COVID-19 pandemic introduced new forms of insecurity in the working life and beyond. Third, all our informants were 55 or older and still employed. This implies that we have excluded workers with unstable work contracts and/or health problems, who are often excluded from the working life by 55. Also, our informants owned homes in the Oslo region, where housing prices are higher than anywhere else in Norway. Taken together, these suggest that our informants were all comparatively well off. Worries about the future may be more prominent among older workers who are less resourceful and more vulnerable to labor market exclusion. Also, the concerns of older workers in Norway-even resourceful older workers-may change over time as the new pension system matures and the life expectancy adjustment lowers pension amounts for everybody. Indeed, the ways in which different opportunities and different adaptations to a flexible system will affect patterns of inequality in old age will be an important topic for future research.

\section{References}

Almenberg, J. \& Säve-Söderbergh, J. (2011). Financial literacy and retirement planning in Sweden, Journal of Pension Economics and Finance 10(4): 585-598. doi: https://doi. org/10.1017/S1474747211000497.

Barr, N. (2014). The Role of Public and Private Sectors in Ensuring Adequate Pensions: Theoretical Considerations. In B. J. Clements, F. Eich, \& S. Gupta (Eds.), Equitable and Sustainable Pensions: Challenges and Experience. Washington: International Monetary Fund.

Bergene, A. C. \& Drange, I. (2015). «Pensjon? Hvafforno?». Kunnskap og informasjonsbehov om pensjon [«Pension? What?». Knowledge and information need about pensions], Søkelys på arbeidslivet 32(3): 261-278.

Bjørnstad, A. F. (2019). Utviklingen i pensjonering og sysselsetting blant seniorer [Trends in retirement and employment among senior workers], Arbeid og velferd (2): 89-100.

Boisclair, D., Lusardi, A. \& Michaud, P.-C. (2017). Financial literacy and retirement planning in Canada, Journal of Pension Economics and Finance 16(3): 277-296. doi: https://doi. org/10.1017/S1474747215000311.

Breit, E. \& Salomon, R. (2015). Making the technological transition - Citizens' encounters with digital pension services, Social Policy \& Administration 49(3): 299-315. doi: https:// doi.org/10.1111/spol.12093.

Brown, P. \& Vickerstaff, S. (2011). Health subjectivities and labor market participation: Pessimism and older workers' attitudes and narratives around retirement in the United Kingdom, Research on Aging 33(5): 529-550. doi: https://doi.org/10.1177\%2F01640 27511410249.

Chan, S. \& Stevens, A. H. (2008). What you don't know can't help you: Pension knowledge and retirement decision-making, The Review of Economics and Statistics, 90(2): 253-266. doi: https://doi.org/10.1162/rest.90.2.253.

Dahl, E. S. \& Galaasen, A. M. (2013). I pose og sekk? Hvorfor har så mange valgt å kombinere arbeid og pensjon? [Have your cake and eat it, too? Why have so many chosen to combine work and retirement?], Arbeid og velferd (3): 56-66.

Downs, A. (1957). An economic theory of democracy, New York: Harper and Brothers. 
Ebbinghaus, B. (2011). The Varieties of pension governance: pension privatization in Europe, Oxford: Oxford University Press.

Ekerdt, D., Hackney, J., Kosloski, K. \& DeViney, S. (2001). Eddies in the Stream: The prevalence of uncertain plans for retirement, The Journals of Gerontology, Psychological Sciences and Social Sciences 56B(3): 162-170. doi: https://doi.org/10.1093/geronb/56.3.S162.

Ellingsæter, A. L. \& Jensen, R. S. (2019). Politicising women's part-time work in Norway: A longitudinal study of ideas, Work, Employment and Society 33(3): 444-446. doi: https:// doi.org/10.1177\%2F0950017018821277.

Ellingsæter, A. L. \& Pedersen, E. (2016). Institutional trust: Family policy and fertility in Norway, Social Politics: International Studies in Gender, State \& Society 23(1): 119-141. doi: https://doi.org/10.1093/sp/jxv003.

Epland, J. \& Thorsen, L. R. (2019). Vedvarende lavinntekt [Persistent low income]. In E. L. Omholt (Ed.), Økonomi og levekår for lavinntektsgrupper 2019 [Economic situation and living conditions of low-income groups 2019], Rapporter 2019/33, Oslo: Statistics Norway.

Eurostat (2019). Employment rate of older workers, age group 55-64. Available at: https://ec.europa.eu/eurostat/web/products-datasets/product? code=tesem050. Accessed April 26, 2021.

Gilleard, C. \& Higgs, P. (2000). Cultures of ageing. Self, citizen and the body, Oxford/New York: Routledge.

Grødem, A. S. \& Hippe, J. M. (2020). How occupational pensions shape extended working lives: Gender, class and chance after the Norwegian Pension Reform, Work, Employment and Society 1-18. doi: https://doi.org/10.1177\%2F0950017020952619.

Grødem, A. S. \& Kitterød, R. H. (2021). Older workers imagining retirement: the collapse of agency, or freedom at last? Ageing and Society, 1-19. doi: https://doi.org/10.1017/ S0144686X20002044.

Hagelund, A. \& Grødem, A. S. (2017). Build your own pension: Framing pension reform and choice in newspapers, Journal of Aging \& Social Policy 29(3), 218-234. doi: https://doi. org/10.1080/08959420.2016.1242108.

Hagelund, A. \& Grødem, A. S. (2019). When metaphors become cognitive locks: occupational pension reform in Norway, Policy and Society, 1-16. doi: https://doi.org/10.1080/144 94035.2019.1646070. April 26.

Hellevik, T. \& Herlofson, K. (2020). 67+ and still working. Nordisk välfärdsforskning | Nordic Welfare Research 5(2): 95-108. doi: https://doi.org/10.18261/issn.2464-4161-202002-03 ER.

Hermansen, Å. \& Midtsundstad, T. (2013). Kjennskap til arbeidsmarkedsbaserte pensjoner i privat sektor [Knowledge about labor-market based pensions in the private sector], Søkelys på arbeidslivet 30(1-2): 107-123.

Hippe, J. M., Hammer, H. \& Vøien, H. G. (2018). Nok pensjon? Etter pensjonsreformen: effekter av ny folketrygd, AFP og tjenestepensjoner [Sufficient pensions? After the pension reform: effects of new National Insurance pension, AFP and occupational pension schemes], Rapport 2018:17, Oslo: Fafo.

Hippe, J. M., Lillevold, P. \& Vøien, H. G. (2017). Alle skal med? En analyse av frafall i AFP-ordningen [Everyone included? An analysis of dropouts from the AFP pension scheme], Søkelys på arbeidslivet 34(1-2): 5-23. doi: https://doi.org/10.18261/issn.15047989-2017-01-02-01.

James, H., Price, D. \& Buffel, T. (2020). How do people think about later life when making workplace pension saving decisions?, Journal of Aging Studies 54, doi: https://doi. org/10.1016/j.jaging.2020.100869.

Jensen, P. H. (2020). On how different combinations of conditions produce different early exit/retirement outcomes: a qualitative (case-oriented) comparison of Denmark and Sweden, Ageing and Society, 1-21. doi: https://doi.org/10.1017/S0144686X2000029X. 
Lien, O. C. (2012). Når bør man ta alderspensjon? [When should you draw old age pension?], Arbeid og velferd (1): 62-72.

Moffatt, S. \& Heaven, B. E. N. (2017). 'Planning for uncertainty': narratives on retirement transition experiences, Ageing and Society 37(5): 879-898. doi: https://doi.org/10.1017/ S0144686X15001476.

Newall, P. W. S. \& Peacey, M. W. (2021). Pension behavior and policy, Journal of Behavioral and Experimental Finance 29(March): 10049. doi: https://doi.org/10.1016/j.jbef.2020. 100449.

Nivalainen, S., Tenhunen, S. \& Järnefelt, N. (2020). Carrots, sticks and old-age retirement. A review of the literature on the effects of the 2005 and 2017 pension reforms in Finland. Nordisk välfärdsforskning I Nordic Welfare Research 5(2): 83-94. doi: https:// doi.org/10.18261/issn.2464-4161-2020-02-02.

OECD. (2017). G20/OECD INFE report on adult financial literacy in G20 countries. Hamburg: OECD.

OECD. (2019). Pensions at a Glance 2019, Paris: OECD.

Pedersen, A. W. (2017). ESPN thematic report: Assessment of pension adequacy in Norway, 2017, Brussels: European Commission \& European Social Policy Network.

Pensjonspolitisk arbeidsgruppe, 2020. Arbeid, pensjon og inntekt i den eldre befolkningen regjeringen.no[Work, pension and income in the elderly population].

Prabhakar, R. (2017). Why do people opt-out or not opt-out of automatic enrolment? A focus group study of automatic enrolment into a workplace pension in the United Kingdom, Journal of European Social Policy 27(5): 447-457. doi: https://doi.org/10.1177\% 2F0958928717717656.

Price, D., Bisdee, D., Daly, T., Livsey, L., \& Higgs, P. (2014). Financial planning for social care in later life: The 'shadow' of fourth age dependency, Ageing and Society 34(3): 388-410. doi: https://doi.org/10.1017/S0144686X12001018.

Price, D., \& Livsey, L. (2015). Money and later life, Routledge Handbook of Cultural Gerontology, pp. 305-312.

Salomon, R. H. \& Solem, P. E. (2020). Nordic responses to extending working life. Nordisk välfärdsforskning I Nordic Welfare Research 5(2): 75-82. doi: https://doi.org/10.18261/ issn.2464-4161-2020-02-01.

St.meld. nr. 5 (2006-2007). Opptjening og uttak av alderspensjon i folketrygden [Accrual and take-up of National Insurance pension], Oslo: Stortinget.

Vickerstaff, S. (2006). Entering the retirement zone: How much choice do individuals have? Social Policy and Society 5(4): 507-517. doi: https://doi.org/10.1017/S147474640600 3265.

Vickerstaff, S. \& Cox, J. (2005). Retirement and risk: The individualisation of retirement experiences?, The Sociological Review 53(1): 77-95. doi: https://doi.org/10.1111\%2Fj.1467954X.2005.00504.x. 


\section{Appendix. List of informants}

\begin{tabular}{|c|c|c|c|c|}
\hline$\#$ & Gender/Age & Education & Work & Partner/Children \\
\hline 1 & Man/56 & Low & Finance manager & Married/3 \\
\hline 2 & Woman/56 & High & Project manager in bank & Married/3 \\
\hline 3 & Woman/60 & Low & Kindergarten assistant, $40 \%$ & Married/2 \\
\hline 4 & Woman/55 & Medium & Flight attendant & No partner/2 \\
\hline 5 & Man/58 & Medium & Manager & Married/3 \\
\hline 6 & Man/59 & High & Secretariat, NGO & Married/2 \\
\hline 7 & Woman/57 & Low & Sales & Married/I \\
\hline 8 & Woman/56 & Medium & Building manager & Married/I \\
\hline 9 & $\operatorname{Man} / 63$ & Medium & Construction manager & Married/2 \\
\hline 10 & $\operatorname{Man} / 64$ & Medium & Electrical power supply & Cohabiting/2 \\
\hline 11 & Woman/6I & Low & Kindergarten, senior position & No partner/2 \\
\hline 12 & Woman/63 & Medium & IT security & Married/4 \\
\hline 13 & $\operatorname{Man} / 60$ & Medium & Health worker & Married/4 \\
\hline 14 & Woman/64 & Medium & Creative enterprise & Married/2 \\
\hline 15 & $\operatorname{Man} / 65$ & High & Sales manager & Married/2 \\
\hline 16 & $\operatorname{Man} / 64$ & High & IT development, 80\% & Married/3 \\
\hline 17 & $\operatorname{Man} / 64$ & Low & Transport & Married/2 \\
\hline 18 & Woman/63 & Low & Publishing & Married/2 \\
\hline 19 & Woman/63 & Low & Reception & Cohabiting/I \\
\hline 20 & $\operatorname{Man} / 64$ & Medium & Engineer & Married/I \\
\hline 21 & Woman/64 & Low & Administrator (education) & Married/2 \\
\hline 22 & Woman/64 & Medium & Sales & Married/2 \\
\hline 23 & $\operatorname{Man} / 56$ & High & Sales (strategic planning) & Married/2 \\
\hline 24 & $\operatorname{Man} / 64$ & Medium & Oil industry & Married/5 \\
\hline 25 & $\operatorname{Man} / 66$ & Medium & Economist & Married/2 \\
\hline 26 & Woman/65 & High & International affairs & Married/2 \\
\hline 27 & Man/55 & Medium & Project manager & No partner/2 \\
\hline 28 & $\operatorname{Man} / 63$ & High & Hydropower & Married/3 \\
\hline
\end{tabular}

